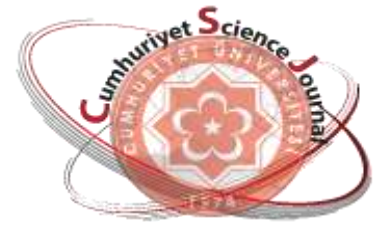

e-ISSN: $2587-246 X$

ISSN: $2587-2680$

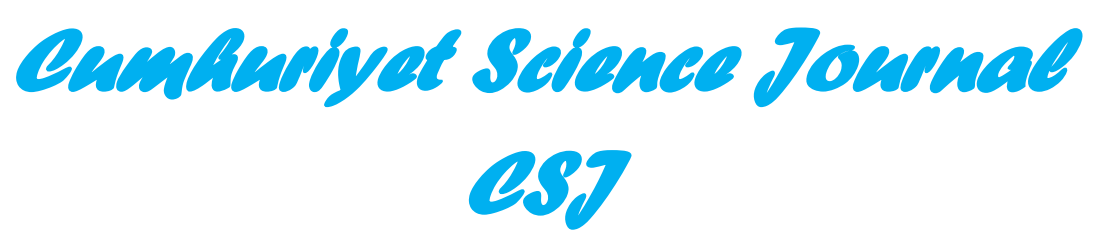

Cumhuriyet Sci. J., Vol.39-3(2018) 573-580

\title{
Antibacterial and Antioxidant Activities of Ocimum basilicum L. Against Mastitis Pathogens
}

\author{
Gulten OKMEN ${ }^{1 *}$, Neslihan BALPINAR ${ }^{2}$ \\ ${ }^{I}$ Mugla Sitki Kocman University, Faculty of Science, Department of Biology, Mugla, TURKEY \\ ${ }^{2}$ Burdur Mehmet Akif Ersoy University, Faculty of Arts and Sciences, Department of Biology, Burdur, TURKEY
}

Received: 26.03.2018; Accepted: 24.09.2018

http://dx.doi.org/10.17776/csj.409675

\begin{abstract}
The most common bacterial agents cause inflammation in the mammary gland (mastitis), which disease cause to less yields in cows. These bacteria are Staphylococcus aureus and Coagulase-negative Staphylococci (CNS). Therefore, these bacteria were selected in this study. The purpose of this study is to research the antibacterial and antioxidant potential of the various extracts of Ocimum basilicum L. The mastitis agents used in the study are 7 bacteria in total; 2 of them are Staphylococcus aureus and the other 5 bacteria are CNS. The antibacterial activities studies were carried out using Kirby-Bauer disc diffusion technique. The other antibacterial activity test performed within the scope of this study was minimum inhibitory concentration (MIC) test. Antioxidant activities were determined by 2,2-diphenyl-1-picrylhydrazyl (DPPH) radical scavenging method. This study showed that the largest inhibition zone was obtained from the methanol extract of $O$. basilicum. Result of this study is $9 \mathrm{~mm}$. The lowest MIC value was recorded as 3250 $\mu \mathrm{g} / \mathrm{mL}$. It was found that $O$. basilicum used in the study had antibacterial activity against mastitis pathogens, and high antioxidant activity could be obtained from the water extracts $(72 \%)$. Consequently, O. basilicum is a good candidate in developing new antibacterial and antioxidant agents.
\end{abstract}

Keywords: Antibacterial activity, Antioxidant activity, Mastitis, Ocimum basilicum.

\section{Mastitis Patojenlerine Karşı Ocimum basilicum L.' un Antibakteriyel ve Antioksidan Aktiviteleri}

\begin{abstract}
Özet. En yaygın bakteriyel ajanlar meme bezlerinde iltihaplanmaya (mastitis) neden olmakta, ki bu hastalık ineklerde düşük verime neden olur. Bu bakteriler Staphylococcus aureus ve koagülaz-negatif Staphylococci (KNS)'dir. Bu çalışmanın amacı, Ocimum basilicum L.'nin çeşitli özütlerinin antibakteriyel ve antioksidan potansiyellerinin araştırılmasıdır. Çalışmada kullanılan mastitis etkenleri toplam 7 bakteri olup, bunlardan 2 tanesi Staphylococcus aureus, diğer 5 bakteri ise KNS'dir. Antibakteriyel aktivite çalışmaları Kirby-Bauer disk difüzyon metodu kullanılarak gerçekleştirilmiştir. Bu çalışma kapsamında yapılan diğer bir antibakteriyel aktivite testi, minimum inhibitör konsantrasyon (MIK) testidir. Antioksidan aktivite çalışmaları 2,2-difenil-1pikrilhidrazil (DPPH) radikal süpürme yöntemi ile belirlenmiştir. Çalışma en geniş inhibisyon zonunun, $O$. basilicum'un metanol özütünden sağlandığını göstermiştir. Bu çalışmanın sonucu 9 mm'dir. En düşük MíK değeri $3250 \mu \mathrm{g} / \mathrm{mL}$ olarak kayıt edilmiştir. Çalışmada kullanılan $O$. basilicum, mastitis patojenlerine karşı antibakteriyel aktiviteye sahiptir ve yüksek antioksidan aktivite sulu özütlerden elde edilmiştir (\%72). Sonuç olarak, yeni antibakteriyel ve antioksidan ajanların geliştirilmesinde, $O$. basilicum' un iyi bir aday olduğunu ortaya koymaktadır.
\end{abstract}

Anahtar Kelimeler: Antibakteriyel aktivite, Antioksidan aktivite, Mastitis, Ocimum basilicum.

\footnotetext{
* Corresponding author. Email address: gultenokmen@gmail.com http://dergipark.gov.tr/csj @2016 Faculty of Science, Cumhuriyet University
} 


\section{INTRODUCTION}

The milk from a healthy cow under hygienic conditions contains only a limited number of microorganisms in the teat canal. The main sources of contamination can be environment, milking equipment and even more milker his/herself [1]. The most common bacterial agents causing inflammation in the mammary gland (mastitis) are coliform bacteria, Staphylococcus and Streptococcus [2]. Among these agents, Staphylococcus aureus has been commonly reported for many years [3]. Coagulase-negative Staphylococci (CNS) have been more isolated in recent years in comparison with the far past. This indicates that mastitis has attracted much research interest recently [4].

Subclinical mastitis infection continues to spread among the cows, while clinical mastitis is seen as sporadic cases. And hence the disease can be transmitted to other cows in the herd [5]. Mastitis leads to high economic losses in livestock breeding industry. It is reported that because of mastitis, worldwide annual losses reach 35 billion dollars [6].

The prolonged use of antibiotics in the treatment of mastitis causes the development of antibiotic resistant in bacterial strains, thus triggers increasing in dose of antibiotics, which finally leads to the occurrence of antibiotic in milk [7]. The development of antibiotic resistance in $S$. aureus via the contaminated milk affects the environment to a great extent, and such bacteria can infect humans via direct contact or food chains [8]. For this reason, today's scientists focus on discovery and application of new antibiotics against bacterial agents that have developed resistance to many antibiotics.

Ocimum basilicum L. belongs to Lamiaceae family. This is an annual, herbaceous plant that is 15-60 cm height in pink or white blooms. The plant is originally native to Africa, Asia and America, and it is also cultivated in the Southwest Asia and Europe (especially the Mediterranean countries) including Turkey [9]. More than 65 species of this genus are commercially cultivated in many countries [10]. In the food industry, its spices or volatile oils are widely used in soft drinks, candies, vines, meat and flavouring products [11]. It is also used in perfume making [12]. The plant has sedative, flatulence and diuretic effects [13]. The volatile oils obtained from this plant have been studied since 1930 and over 200 chemical compounds have been found [14]. It is formed by terpenoids and phenylpropanoids such as citral, eugenol, methyl eugenol and chavicol [15]. The extracts of the leaves of Ocimum basilicum exhibit antiviral, anticancer, antiaging, antioxidant and antibacterial properties [16-20]. Such pharmacological effetcs come from its polyphenolic contents [21].

The most common bacterial agents cause inflammation in the mammary gland (mastitis), which disease cause to less yields in cows. These bacteria are Staphylococcus aureus and Coagulase-negative Staphylococci (CNS). Therefore, these bacteria were selected in this study. This study aims to analyse the biological activities of $O$. basilicum against mastitis pathogens and to contribute some information on these activities in the extant literature. Although several studies on the biological activities of these species are already exist in the literature [22-24], the antioxidant and antibacterial activities of $O$. basilicum, which is widely grown and used in Mugla/Turkey, against mastitis pathogens have not been extensively investigated.

\section{MATERIALS and METHODS}

\subsection{Plant material}

The leaves of Ocimum basilicum was collected from local markets (C2 region/Mugla/Turkey). The material was identified by Dr. Neslihan Balpinar and stored at the Department of Biology at Mugla Sitki Kocman University. The identification of plant material was made according to "Flora of Turkey and the East Aegean Islands" [25-27]. 


\subsection{Microorganisms}

The mastitis agents in this study are 7 bacteria in total; 2 of them are $S$. aureus and the other 5 bacteria are Coagulase-negative Staphylococci (CNS). All mastitis pathogens were supplied from Dr. Zafer Cantekin's Project that has been completed previously [50]. The diagnosis of the pathogens was performed using biochemical tests with classical culture methods [28].

\subsection{Preparation of the plant material}

The leaves of Ocimum basilicum used in the analysis of the antibacterial activity were washed several times under running and distilled water. The distilled water was sterile. The leaves of plant were dried at room temperature in a laboratory and then powdered in a blender. During the preparation of the samples, all the materials were kept at room temperature.

\subsection{Extraction process}

The powdered plant leaves $(50 \mathrm{~g})$ were processed using a soxhlet extractor (Isotex). In this process, it was used the solvents of ethanol, methanol and water. The extracts were evaporated under a fume hood and transferred into sterilized opaque falcon tubes containing their own solvents. The concentrations of all extracts were set at 150 $\mathrm{mg} / \mathrm{mL}$, and they were preserved in a refrigerator until analysis. The temperature was $+4^{\circ} \mathrm{C}$.

\subsection{Cultivation of microorganisms}

Mastitis agents were used as a source of microorganisms. The extracts were analysed one by one against mastitis agents. The bacteria used in the study were cultivated in Mueller-Hinton Broth (MHB, Merck) medium. Incubation was carried out at $37^{\circ} \mathrm{C}$ for $24 \mathrm{~h} \mathrm{[29].}$

\subsection{In vitro antimicrobial assay}

The Bauer-Kirby method was used to this activity [30]. The various extracts of the leaves (150 $\mathrm{mg} / \mathrm{mL}$ ) were analysed by the disk diffusion method. The ethanol, methanol and water extracts were used at the analyses. Test bacteria inoculated on Mueller-Hinton Agar (MHA, Merck) medium were grown at an incubator. The temperature of this study was $37^{\circ} \mathrm{C}(24 \mathrm{~h})$. The turbidities of the cultures were set to $0.5 \mathrm{McF}$ arland. Inhibition zones occurring after the incubation were recorded in $\mathrm{mm}$ scale. Standard antibiotic discs (ampicillin $10 \mu \mathrm{g}$; oxacillin $5 \mu \mathrm{g}$ ) were used as positive controls while solvents were tested as negative controls against the test pathogens. All measurements were performed in triplicate.

\subsection{Minimum inhibitory concentration (MIC)}

The other antibacterial activity test applied to bacteria was minimum inhibitory concentration (MIC). The experiments were performed by broth dilution assay as defined in CLSI standards [31, 32]. The MIC values of extracts were recorded after the incubation. The concentrations of extracts were set to $13000,6500,3250,1625$ and $812.5 \mu \mathrm{g} / \mathrm{mL}$.

\subsection{Detection of non-enzymatic antioxidant activities}

In this study, 2,2-diphenyl-1-picrylhydrazyl (DPPH) was used as free radical. Stable DPPH was used to determine the antioxidant capacities of the extracts. The $0.1 \mathrm{~mL}$ of extracts were added to $3.9 \mathrm{~mL}$ of the methanolic DPPH solution. The concentration of this solution was $0.1 \mathrm{mM}$. After waiting for $30 \mathrm{~min}$, the absorbances were measured at a wavelength of $515 \mathrm{~nm}$ in a spectrophotometer. The methanolic DPPH solution was employed as a control while methanol was utilized as the blank. Trolox was used as reference in this assay. The results were given in percentage (\%) [33].

\section{RESULTS}

The antibacterial activities of the various extracts obtained from Ocimum basilicum were tested against mastitis agents. The results were summarized and compared to the standard antibiotics in Table 1. Having taken a closer look at the data obtained from this study, it was seen that the highest inhibition zone was obtained from 
the methanol extract, and this zone diameter was 9 $\mathrm{mm}$. Most of extracts have antibacterial activities against the mastitis pathogens. These inhibition zones are lower than zones of antibiotics (Table 1). As shown in the results, the ethanol and methanol extracts exhibit a big inhibition zone ( 9 $\mathrm{mm}$ ) against Staphylococcus aureus -18 and CNS-22. The solvents used as negative controls have no antibacterial activities against microorganisms (Table 1).

Table 1. The antibacterial activities of the various extracts of Ocimum basilicum $(150 \mathrm{mg} / \mathrm{mL})$ against mastitis pathogens.

\begin{tabular}{|c|c|c|c|c|c|c|c|c|}
\hline \multirow{2}{*}{ Bacteria } & \multicolumn{3}{|c|}{ Inhibition zone (mm) } & \multicolumn{2}{|c|}{ Antibiotics (mm) } & \multicolumn{3}{|c|}{ Solvents } \\
\hline & $\mathrm{EE}$ & $\mathrm{ME}$ & WE & $\mathrm{AM}$ & $\mathrm{O}$ & $\mathrm{E}$ & M & $\mathrm{W}$ \\
\hline S. aureus-17 & 7 & - & - & 18 & 10 & - & - & - \\
\hline S. aureus-18 & 8 & 9 & - & 12 & 8 & - & - & - \\
\hline CNS-22 & 8 & 9 & 8 & - & - & - & - & - \\
\hline CNS-32 & - & - & - & 10 & 7 & - & - & - \\
\hline CNS-33 & 8 & 8 & - & 8 & 7 & - & - & - \\
\hline CNS-36 & - & - & 7 & - & - & - & - & - \\
\hline CNS-37 & - & - & - & - & - & - & - & - \\
\hline
\end{tabular}

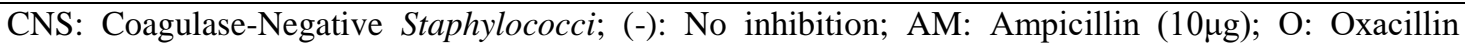
$(5 \mu \mathrm{g})$; EE: Ethanol extract; ME: Methanol extract; WE: Water extract

The minimum inhibitory concentration (MIC) results of the various extracts of $O$. basilicum are summarized in Table 2. In this study, different concentrations of extracts were worked for antibacterial activities. This test was applied to the extracts with antibacterial activity, and the lowest MIC value $(3250 \mu \mathrm{g} / \mathrm{mL})$ was found in the ethanol extracts (Table 2). The MIC values for CNS-22 and CNS-36 could not be determined until 13000 $\mu \mathrm{g} / \mathrm{mL}$ concentration.

Table 2. The MIC results of the various extracts of Ocimum basilicum $(\mu \mathrm{g} / \mathrm{mL})$.

\begin{tabular}{cccc}
\hline Bacteria & Ethanol extract & Methanol extract & Water extract \\
\hline S. aureus -17 & 6500 & $(\mathrm{nt})$ & $(\mathrm{nt})$ \\
S. aureus -18 & 6500 & 6500 & $(\mathrm{nt})$ \\
CNS-22 & 13000 & 6500 & - \\
CNS-32 & $(\mathrm{nt})$ & $(\mathrm{nt})$ & $(\mathrm{nt})$ \\
CNS-33 & 3250 & 6500 & $(\mathrm{nt})$ \\
CNS-36 & $(\mathrm{nt})$ & $(\mathrm{nt})$ & - \\
CNS-37 & $(\mathrm{nt})$ & $(\mathrm{nt})$ & $(\mathrm{nt})$ \\
\hline
\end{tabular}

(nt): not tested; (-): No MIC was observed at concentrations tested up to $13000 \mu \mathrm{g} / \mathrm{mL}$.

The antioxidant activities of the various extracts of $O$. basilicum were also examined and the data obtained from this examination were summarized in Table 3. The water extract of $O$. basilicum had the highest antioxidant activity (72\%). On the other hand, activities of the ethanol and methanol extracts were $13.6 \%$ and $23.4 \%$, respectively (Table 3).

Table 3. The antioxidant activities of the various extracts of Ocimum basilicum (\%) and their trolox equivalent.

\begin{tabular}{|c|c|c|c|c|c|c|}
\hline \multirow{2}{*}{$\begin{array}{c}\text { Plant material } \\
(150 \mathrm{mg} / \mathrm{mL})\end{array}$} & \multicolumn{2}{|l|}{$\mathrm{EE}$} & \multicolumn{2}{|c|}{$\mathrm{ME}$} & \multicolumn{2}{|c|}{ WE } \\
\hline & DPPH $(\%)$ & TE & DPPH (\%) & $\mathrm{TE}$ & DPPH (\%) & $\mathrm{TE}$ \\
\hline Ocimum basilicum & 13.6 & 1.3 & 23.4 & 1.67 & 72 & 2.1 \\
\hline
\end{tabular}

EE: Ethanol extract; ME: Methanol extract; WE: Water extract; TE: Trolox equivalent (mM TE/g DW); DW: dry weight

\section{DISCUSSION}

Our study showed that most of the ethanolic extracts of the plant inhibited the development of the mastitis pathogens and the inhibition zones were 7-8 mm (Table 1). Suppakul et al. [34] noted that the essential oil of sweet Ocimum basilicum had a broad antimicrobial spectrum. Wannissorn 
et al. [17] reported that the volatile oil obtained from $O$. basilicum had remarkable antibacterial effects. However, Bozin et al. [18] and López et al. [35] reported that Gram-positive bacterial strains showed a high susceptibility to $O$. basilicum essential oils. In other study, Shafique et al. [36] tested the leaf extracts of $O$. basilicum against 8 bacteria using disc diffusion assay, and found that the extracts of the plant were highly effective against Gram-positive bacteria. Yahya [37] applied the concentrations of 0.34-10.96 $\mathrm{mg} / \mathrm{mL}$ of $O$. basilicum to Staphylococcus aureus, and observed that the development was inhibited. For the concentrations of 20 and $100 \mathrm{mg} / \mathrm{mL}$, Yahya found the inhibition zones of 12 and 20 mm, respectively. Unnithan et al. [38] stated that the extracts of $O$. basilicum had significant antibacterial activity against Gram-positive bacteria ( $S$. aureus) when compared to Gramnegative ones (Escherichia coli). These results support our findings. In the extant literature, antimicrobial mechanisms of volatile oils and extracts of herbs are explained by degrade cell membranes [39], cytoplasmic membrane damage [40], membrane protein damage [41], leakage of cell contents [39], coagulation of cytoplasm [42] and proton motive power reduction [43]. Antimicrobial activities of the essential oils of the plant are related to the presence of high linalool content [34].

In this study, the water extracts of plant did not inhibit the growths of many mastitis pathogens (Table 1). Some components such as camphor, eugenol, estragole, 1,8-cineole and linalool that have antimicrobial characteristics are known to be biologically active [44]. These differences indicates that essential oil composition is associated with environmental and genetic factors, chemotypes and nutritional status of the plant [45].

The lowest minimum inhibitory concentration (MIC) value $(3250 \mu \mathrm{g} / \mathrm{mL})$ in our study was obtained from ethanol extracts (Table 2). Alsabri et al. [46] determined the MIC value of Arbutus pavarii against $S$. aureus to be $4.86 \mathrm{mg} / \mathrm{mL}$. Alsabri's result is higher than result of this study.
In the present study, the antioxidant activities of various extracts of $O$. basilicum were also analysed (see Table 3). The highest antioxidant activity of $O$. basilicum was determined as $72 \%$ for the water extract. The antioxidant activity is due to phenolic and flavonoid compounds in the composition [20]. In another study, it has been reported that $O$. basilicum have a high monoterpene level (93\%), especially contains methyl chavicol (85\%), eugenol (0.7\%) and phenolic compounds, and hence it has antioxidant activity [47]. Zhang et al. [48] reported a large number of components belonging to $O$. basilicum. In the development period, the seasonal changes in temperature and humidity generally affect the chemical composition of its volatile oils, antimicrobial and antioxidantive activities of $O$. basilicum [49].

\section{CONCLUSION}

The study suggests that Ocimum basilicum which is grown in Mugla/Turkey can be employed as natural antibacterial agent against mastitis pathogens. However, further investigations concerning bioactive and phytochemical compounds of this plant are needed. In addition, the wider bacterial populations must be included in the study.

\section{Conflicts of interest}

The authors stated that did not have conflict of interest.

\section{REFERENCES}

[1] Khan S.A., Nawaz M.S., Khan A.A. and Cerniglia C.E., Transfer of erythromycin resistance from poultry to human clinical strains of Staphylococcus aureus, J. Clin. Microbiol., 38-5 (2000) 1832-1838.

[2] Morin D.E., Constable P.D. and Mc Coy G.C., Use of clinical parameters for differentiation of Gram-positive and Gramnegative mastitis in dairy cows vaccinated against lipopolysaccharide core antigens, J. Am. Vet. Med. Assoc., 212-9 (1998) 14231431. 
[3] Karahan M., Açık M.N. and Çetinkaya B., Investigation of toxin genes by polymerase chain reaction in Staphylococcus aureus strains isolated from bovine mastitis, Foodborne Pathog. Dis., 6-8 (2009) 1-7.

[4] Taponen S., Simojoki H., Haveri M., Larsen H.D. and Pyorala S., Clinical characteristics and persistence of bovine mastitis caused by different species of coagulase-negative Staphylococci identified with API or AFLP, Vet. Microbiol., 115 (2006) 199-207.

[5] Mustafa Y.S., Awan F.N., Zaman T., Chaudhry S.R. and Zoyfro V., Prevalence and antibacterial susceptibility in mastitis in buffalo and cow in and around the district Lahore-Pakistan, Pak. J. Pharm., 24 (2011) 29-33.

[6] Wellenberg G.L., Van der Poel W.H.M. and Van O.J.T., Viral infections and bovine mastitis: a review, Vet. Microbiol., 88-1 (2002) 27-45.

[7] Dhanabalan R., Doss A., Jagadeeswari M., Balachandar S. and Kezia E., In vitro phytochemical screening and antibacterial activity of water and methanolic leaf extracts of Tridax procumbens against bovine mastitis isolated Staphylococcus aureus, Ethnobot. Leaflets, 12 (2008) 1090-1095.

[8] Turutoglu H., Hasoksuz M., Ozturk D., Yildirim M. and Sagnak S., Methicillin and aminoglycoside resistance in Staphylococcus aureus isolates from bovine mastitis and sequence analysis of their mecA genes, Vet. Res. Commun., 33-8 (2009) 945-956.

[9] Politeo O., Jukica M. and Milosa M., Chemical composition and antioxidant capacity of free volatile aglycones from basil (Ocimum basilicum L.) compared with its essential oil, Food Chem., 101-1 (2007) 379385.

[10] Sajjadi S. E., Analysis of the essential oils of two cultivated basil (Ocimum basilicum L.) from Iran, DARU., 14-3 (2006) 128-130.

[11] Bauer K., Garbe D. and Surburg H., Common Fragrance and Flavor Materials. Wiley-VCH, Weinheim, 1997.
[12] Akgül A., Baharat Bilimi ve Teknolojisi. Gıda Teknolojisi Derneği Yayınları, Ankara, 1993.

[13] Baytop T., Türkiye'de Tibbi Bitkilerle Tedavi (Geçmişte ve Bugün). Nobel Tıp Kitapevleri, İstanbul, 1999.

[14] Chang X., Alderson P.G. and Wright C.J., Solar irradiance level alters the growth of basil (Ocimum basilicum L.) and its content of volatile oils, Environ. Exp. Bot., 63 (2008) 216-223.

[15] Zheljazkov V.D., Callahan A. and Cantrell C.L., Yield and oil composition of 38 basil (Ocimum basilicum L.) accessions grown in Mississippi, J. Agric. Food Chem., 56-1 (2008) 241-245.

[16] Lee S.J., Umano K., Shibamoto T. and Lee K.G., Identification of volatile components in basil (Ocimum basilicum L.) and thyme leaves (Thymus vulgaris L.) and their antioxidant properties, Food Chem., 91-1 (2005) 131-137.

[17] Wannissorn B., Jarikasem S., Siriwangchai T. and Thubthimthed S., Antibacterial properties of essential oils from Thai medicinal plants, Fitoterapia, 76-2 (2005) 233-236.

[18] Bozin B., Mimica-Dukic N., Simin N. and Anackov G., Characterization of the volatile composition of essential oils of some Lamiaceae spices and the antimicrobial and antioxidant activities of the entire oils, J. Agric. Food Chem., 54-5 (2006) 1822-1828.

[19] Gülçin I., Elmastaş M. and Aboul-Enein Y.H., Determination of antioxidant and radical scavenging activity of Basil (Ocimum basilicum L. Family Lamiaceae) assayed by different methodologies, Phytother. Res., 214 (2007) 354-361.

[20] Shafique M., Khan J.S. and Khan H.N., Study of antioxidant and antimicrobial activity of sweet basil (Ocimum basilicum) essential oil, Pharmacologyonline, 1 (2011) 105-111.

[21] Bilal A., Jahan N., Ahmed A., Bilal S.N., Habib S. and Hajra S., Phytochemical and pharmacological studies on Ocimum 
basilicum L., Int. J. Curr. Res. Rev., 4 (2012) 73-83.

[22] Nacar S. and Tansi S., Chemical components of different basil (Ocimum basilicum L.) cultivars grown in Mediterranean regions in Turkey, Isr. J. Plant Sci., 48-2 (2000) 109112.

[23] Adıgüzel A., Güllüce M., Şengül M., Öğütcü H., Şahin F. and Karaman I., Antimicrobial effects of Ocimum basilicum (Labiatae) extract, Turk. J. Botany, 29-3 (2005) 155160.

[24] Telci I., Bayram E., Y1lmaz G. and Avc1 B., Variability in essential oil composition of Turkish basils (Ocimum basilicum L.), Biochem. Syst. Ecol., 34-6 (2006) 489-497.

[25] Davis, P.H., (1965-1985). Flora of Turkey and The East Aegean Islands, 1-9. Edinburgh University Press, Edinburgh.

[26] Davis P.H., Mill R.R., Tan K., Flora of Turkey and the East Aegean Islands 10. Edinburgh University Press, Edinburgh, (1988).

[27] Güner A., Özhatay N., Ekim T. ad Başer K.H.C., Flora of Turkey and the East Aegean Islands 11. Edinburgh University Press, Edinburgh, (2000).

[28] Quinn P.J., Carter M.E., Markey B.K., Carter G.R., Clinical Veterinary Microbiology. Mosby-Year Book Europe Limited, England,1994.

[29] Habib F., Rind R., Durani N., Bhutto A.L., Buriro R.S., Tunio A., Aijaz N., Lakho S.A., Bugti A.G., Shoaib M., Morphological and cultural characterization of Staphylococcus aureus isolated from different animal species, J. Appl. Environ. Biol. Sci., 5-2 (2015) 1526.

[30] Bauer A.W., Kirby W.M., Sherris J.C. and Turck M., Antibiotic susceptibility testing by a standardized single disk method, Am. J. Clin. Pathol., 45-4 (1966) 493-496.

[31] CLSI (Clinical and Laboratory Standards Institute), Methods for Dilution Antimicrobial Susceptibility Test for Bacteria that Grow Aerobically; Approved Standard M7-A. National Committee for Clinical Laboratory Standards, Philadelphia, 2003.
[32] CLSI (Clinical and Laboratory Standards Institute), Performance Standards for Antimicrobial Susceptibility Testing $\left(16^{\text {th }}\right.$ Informational Supplement M100-S16). National Committee for Clinical Laboratory Standards, Philadelphia, 2006.

[33] Brand-Williams W., Cuvelier M.E. and Berset C., Use of a free radical method to evaluate antioxidant activity, LWT-Food Science and Technology, 28-1 (1995) 25-30.

[34] Suppakul P., Miltz J., Soneveld K. and Bigger S., Antimicrobial properties of basil and its possible application in food packaging, J. Agrig. Food Chem., 51-11 (2003), 3197-3207.

[35] López P., Sánchez C., Batlle R. and Nerin C., Solid and vapor-phase antimicrobial activities of six essential oils: susceptibility of selected foodborne bacterial and fungal strains, J. Agrig. Food Chem., 5-17 (2005), 6939-6946.

[36] Shafique M., Shaista J.K. and Nuzhat H.K., Comparative study for antibacterial potential of in vitro and in vivo grown Ocimum basilicum L. plant extracts, Pak. J. Biochem. Mol. Biol., 44-3 (2011), 113-117.

[37] Yahya N.Z., In vitro and in vivo evaluation of antimicrobial effect of leaves Ocimum basilicum of ethanolic extract against Staphylococcus aureus, Al-Anbar J. Vet. Sci., 4-2 (2011) 67-75.

[38] Unnithan C.R., Dagnaw W., Undrala S. and Subban R., Chemical composition and antibacterial activity of essential oil of Ocimum basilicum of Northern Ethiopia, Int. Res. J. Biological Sci., 2-9 (2013), 1-4.

[39] Helander I.M., Alakomi H.L., Latva-Kala K., Mattila-Sandolm T., Pol I., Smid E.J., Gorris L.G.M. and von Wright A., Characterization of the action of selected essential oil components on Gram-negative bacteria, J. Agric. Food Chem., 46-9 (1998) 3590-3595.

[40] Ultee A., Bennik M.H.J. and Moezelar R., The phenolic hydroxyl group of carvacrol is essential for action against the food-borne pathogen Bacillus cereus, Appl. Environ. Microbiol., 68-4 (2002) 1561-1568. 
[41] Juven B.J., Kanner J., Schved F. and Weisslowicz H., Factors that interact with the antibacterial action of thyme essential oil and its active constituents, J. Appl. Bacteriol., 766 (1994) 626-631.

[42] Gustafson J.E., Liew Y.C., Chew S., Markham J.L., Bell H.C., Wyllie S.G. and Warmingto J.R., Effects of tea tree oil on Escherichia coli, Lett. Appl. Microbiol., 26-3 (1998) 194-198.

[43] Ultee A. and Smid E.J., Influence of carvacrol on growth and toxin production by Bacillus cereus, Int. J. Food Microbiol., 64-3 (2001) 373-378.

[44] Morris J.A., Khettry A. and Seitz E.W.M., Antimicrobial activity of aroma chemicals and essential oils, J. Am. Oil Chem. Soc., 565 (1979) 595-603.

[45] Ozcan M. and Chalchat J.C., Essential oil composition of Ocimum basilicum L. and Ocimum minimum L. in Turkey, Czech J. Food Sci., 20-6 (2002) 223-228.

[46] Alsabri S.G., El-Basir H.M., Rmeli N.B., Mohamed S.B., Allafi A.A., Zetrini A.A., Salem A.A., Mohamed S.S., Gbaj A. and ElBaseir M.M., Phytochemical screening, antioxidant, antimicrobial and antiproliferative activities study of Arbutus pavarii plant, J. Chem. Pharm. Res., 5-1 (2013) 32-36.

[47] Sharafati R.C., Rokni N., Rafieian K.M., Drees F. and Salehi E., Antioxidant and antibacterial activity of basil (Ocimum basilicum L.) essential oil in beef burger, J. Agric. Sci. Technol., 17-4 (2015) 817-826.

[48] Zhang J.W., Li S.K. and Wu W.J., The main chemical composition and in vitro antifungal activity of the essential oils of Ocimum basilicum Linn. var. pilosum (willd.) Benth., Molecules, 14-1 (2009) 273-278.

[49] Vardar U. G., Candan F., Sokmen A., Daferera D., Polissiou M., Sokmen M., Donmez E. and Tepe B., Antibacterial and antioxidant activity of the essential oil and methanol extracts of Thymus pectinatus Fisch. et Mey var. pectinatus (Lamiaceae), J. Agric. Food Chem., 51-1 (2003) 63-67.
[50] Cantekin Z., Ergün Y., İneklerde subklinik mastitis etkenlerinin kültür ve PCR yöntemleriyle karşılaştırmalı tanısı. MKÜ BAP project no: 1101 M 0103, ethics committee no: 2010/02-30: 12. 